\title{
Fru Maria Cornetts breve
}

Ved Holger Jacobsen.

Den 20. maj 1863 var der fest i Åbenrâ. På Andersens skibsværft løb det 161 kommercelæster store barkskib »Johanne Marie « af stabelen. Rederen var sejlmager Jørgen Cornett, født den 8. november 1811, kaptajnen Rasmus Petersen fra Biskopstorp på Fyn. Denne var forlovet med rederens datter Ingeborg, født den 15. maj 1844, og da "Johanne Marie" den 15. august 1863 sejlede fra Åbenrâ over England til Kinakysten, fulgte hun ham som hans unge brud. De var blevet gift den 17 . juni.

Det Cornett'ske hjem var kendt for sin danskhed. Der var det, Frederik Fischer havde holdt sine små møder med andre dansksindede borgere, og det var sejlmagerens mor, der i 1848 henledte linieskibet "Sct. Thomas" opmærksomhed pă, at slesvig-holstenerne var i byen, idet hun lagde soldaternes chakoter i vinduet.

Maria Cornett, Jørgen Cornetts hustru, var født den 18. oktober 1815 som datter af kaptajn Mathias Koch og Maria Dorthea, født Fischer af den kendte danske Fischer'ske slægt. Faderen forliste ved den skotske kyst, da Maria var en 5 års pige, og hun var således fortrolig med de farer, der truede de søfarende. Hun var en betydelig kvinde og blev til sin død i 1911 ved med at interessere sig levende for genforeningen, som hun troede fast pá, støttet af sin veninde den navnkundige Jomfru Fanny. En af hendes døtre, Anna, var gift med J. P. Junggreen.

De folgende breve, som bringes i uddrag, har Maria Cornett skrevet til datteren Ingeborg, medens denne opholdt sig i Kina om bord på »ohanne Marie «. Igennem den moderlige omsorg for den kun nittenårige datter læser man om byen Åbenrås skæbne i de kritiske år 1863-64 og 65. Man læser om opgangstider, indtil krigen bryder ud, om den tunge krigstid og om efterkrigstiden med dens håb og fortrøstning om bedre tider. 


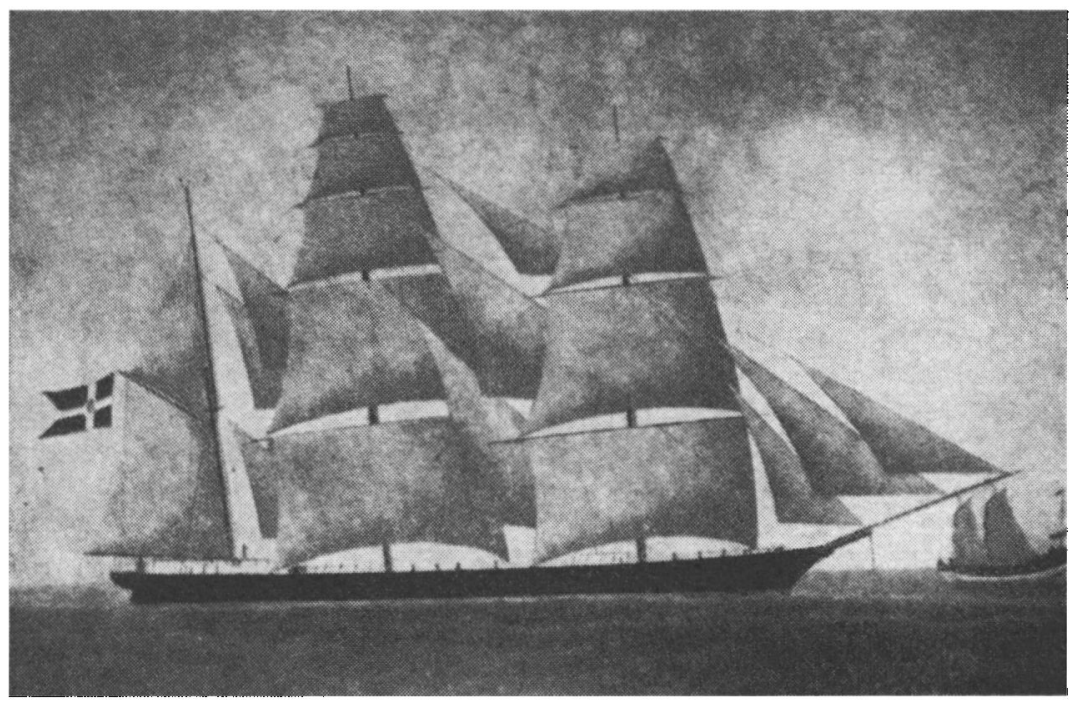

Barken „Johanne Marie“ af Abenrå.

Torsdagen, den 4. august 1863 .

Min kjare Ingeborg.

Du kan tro, det kniber $\mathrm{i}$ dag for mig blot at få en halv time ro til at skrive $i$, da der er så meget at passe. Gas ${ }^{1}$ er bleven indlagt i huset i dag.

...Vi savner Jer begge to sa ofte, men vi tænker dog altid med glæde på Jer, for vi havde det dog så dejligt med den kjære Rasmus. ${ }^{2}$ Han var altid ens og altid god og tilfreds med alt. Vorherre bevare Jer nu på Jeres lange rejse, og at du måtte blive. rask, så går tiden hurtigt hen for os. Det vil vi bede til den gode Gud om, at han vil bevare Eder allesammen, og at vi må samles fornøjet og raske en gang igen. Kjære Rasmus, du sagde til mig. som I gik, at jeg skulde gå op på loftet og se efter Jer, når I kom under sejls, hvad jeg også gjorde. Jeg havde fảet kikkerten ud. Jeg så også, men 1 blev liggende. Bảdene gik fra borde, men det blev ikke til noget. Anna Dals ${ }^{3}$ og Thora Kline var der også. De syntes også, at alt var roligt om bord, hvorpå vi gik ned og satte os og troede, at I kom hjem igen til næste dag. Som vi der sad, kommer Karen og siger, „nå, nu gik de. De gav tre skud, og de er allerede langt ude.“ Det kan nok være, vi kom op igen 
og fik kikkerten udlagt, så træt som jeg var, for jeg havde da nok stâet et par timer før, men du kan ikke tro, sikken et yndigt syn det var at se det dejlige skib med sejlene til.

Som jeg tog kikkerten, kom solen så smukt frem og skinnede på skibet. Det yndige land og skov, som I var ved at forlade for en tid. Det gik mig lige til hjertet, så jeg måtte græde, og dog syntes jeg, jeg følte glæde ved det smukke syn, som Vorherre lod mig se. I kan ikke tænke Eder det, som det dejligste panoramabillede, sådan tænker jeg nu altid på Jer. Jeg synes og tror, at det var et godt tegn, og at Vorherre altid vil lade det lyse for Eder og lade det gå Eder godt, når det også sommetider ser lidt mørkt ud. Du må ikke le af mig kjære Rasmus, fordi jeg have sådanne særheder. Som jeg nu var ene, tænkte jeg, at $I$ ingenting havde glemt, men nu ser jeg til min store glæde, at I dog har ladet noget ligge, for det er godt, når I glemmer noget, så kommer I igen. Det ved Ingeborg nok. Du har glemt 4 skjorter, 2 natskjorter. Ingeborg har glemt hendes sorte silkeforklæde, som var pakket fuld af mindre gjenstande. Hun har lagt det $i$ det lille kammer, som hun stod i tilsidst. Du og din lille kone har det vist rigtig godt. Husk på, hun får nogen pinde til strikning og vadt. Et silkeforklæde må hun vist have. Jeres sager skal jeg nok vare til I kommer hjem en gang. Tusind hilsen fra hele personalet og mange flere fra Cilie, Thilde, Lorenz, ${ }^{5}$ og nu lev vel kjæreste børn, og Gud give Jer en lykkelig rejse. Hils styrmanden og Sophia. Holder I af hende? Gud være med Eder. Det onskes af

Eders hengivne Moder.

Aabenraa u/ dato 1863.

Kjere Ingeborg og Rasmus.

Også et par ord fra mig, inden I tiltræder Eders lange rejse. Gud ske lov at I er lykkelig ankommen, og jeg længes nu meget efter at hore, hvorledes du min kjære Ingeborg har det. Husk nu, ifald du mangler nogen ting, at du får det kjøbt. I kan tro, at Lorenz havde en stor glæde $i$ dag. Tænk, $i$ morges kom der 8 krigsdampere herind og sejlede rundt i fjorden, men gik bort igen. Lorenz og Richard ${ }^{6}$ fik Callsens båd og kom ud, men da det blæste stærkt af øst, kom de dem ikke nær. Der skulle være flere aabenraaere om bord.

Moder. 
Apenrade, den 21. 11. 1863.

Kjere Ingebory.

Når du modtager disse linier, håber jeg, du vil være munter og rask efter din lange sorejse, og Gud give, at du og din kjære Rasmus må beholde sundhed, sålænge I skal være der. Vi savner Jer ofte herhjemme. Møens ${ }^{7}$ har det også rigtig godt. Han har nu alting ene, og alle er så veltilfredse med hans arbejde. Der er meget stærkt byggeri. ${ }^{8}$ Når blot vi må beholde fred, da vores kjære konge er død, og en Augustenburger prinds vil gore sin ret gjældende til Slesvig og Holsten. Christian den 9. er udnævnt til konge, og alting er så vidt på det rene. Jeg kan næsten ikke se mere, derfor må jeg slutte mit brev.

Lev nu vel kjæreste børn og Vorherre bevare Eder.

Eders hengivne mor.

Hilsen fra hele familien og venner.

Aabenraa, den 25. februar 1864.

Min kare Ingeborg.

Da jeg ingen tid kunde få til at skrive, da de andre skrev, begynder jeg $\mathrm{i}$ dag, for at tale lidt med Eder. Vi blev så glade for disse par linier, da vi kunne se, I havde det så godt og var sunde og muntre. Vi derimod har det ikke godt for tiden, da vi altid har huset fuldt af militær. Sundhed have vi gudskelov, som jo er det fornemste, men ellers er det tunge tider. Sindet er trykket på os stakkels dansksindede mennesker at se tusinde og tusinde bevæbnede skarer strømme mod Dybbøl for at slå vores brødre og landesbørn, og så se disse ildesindede mennesker gå og grine ved hvert skud, vi hører, og så at høre om „den store sejer“, og at de kunde jage dem ud af skandserne. Men endnu har deres angreb været uden held, da de danske forsvarer sig med kraft og falder ud af skandserne efter dem og har gjort mange fanger. De fortalte 6-700 mand preussere og Prindsens adjudant.. Det er gandske sandt. I går har de taget et par hundrede mand preussere og 7 kanoner. Man kan nok se på vore hjemmetyskere, at papirerne står dårligt. De går og venter den store sejer, og den bliver borte. Ludvig ${ }^{9}$ er rent tysk og Skifter ${ }^{10}$ er halvt. ${ }^{11}$ Han var $i$ går aftes og drak the med os, Skifter. Han fortalte, at de [preusserne] godt 
kunde tage Dybbol og Als, nâr de vilde, og at de vilde begynde i nat med at gå på, da Tyskerne vilde gå over fra Broager og vilde falde ind på den søndre skandse, men i dag har vi ikke hørt noget, altså vil vi håbe, de danske har heller ikke sovet, omendskjøndt Skifter vilde gjerne have, at jeg skulde tro, at danskerne er ikke så dygtige og have jo ikke så gode kanoner og geværer som Preussen og Østrig, men I kan tro, han får svar. Fader kan han bilde det ind, men mig ikke. Jeg siger, lad dem komme lige mod lige, så kan vi tales ved, men sådan en overlegen fjende. Det er akkurat, som om en 20 karle overfaldt en dreng, så ulige er kampen. „Tyskerne kan jo aldrig, ja aldrig være det bekjendt. Det er jo et overfald, et rovertogt, som aldrig vil blive udslettet $\mathrm{i}$ historien. For en krig kan de store magter ikke være bekjendt på denne måde," svarer jeg dem. Vi har for tiden i standkvarter 4 mand, så I kan tro, vi have nok at tænke på.

Nu skulle I blot se sikken en yndig pige, jeg har fået mig. Tyskerne kalder hende das Fräulein. Hvor er jeg lykkelig. Hun er så akkurat, og køkkenet ser ud som en stadsstue. Om morgenen, når vi kommer ned, står alting parat, og hvor jeg takker Gud, at jeg endelig har fảet en pige, som jeg kan være glad for.

Kjære børn, jeg havde nær glemt det allerbedste at takke Eder for jeres yndige billeder, og vi blev da så glade. Den kjære lille Frederik. ${ }^{12}$ Han sidder på kineserens arm. Hvor er han dog sød med sine små fødder ovenpå hinanden. Du kan tro, de bliver ofte betragtet. Jeg har et forstørrelsesglas af Grossnutters, hvori jeg godt kan se Eder. Du lille Ingeborg er bleven så mager, men, når du ellers er rask, så gør det ingenting. Rasmus ser rigtig godt ud, og den velsignede lille dreng er jo en tyksak. Kineserpigen ser godt ud. Hun er vist $i$ hendes fineste stads. Jeg gist nok høre dig tale med hende kinesisk. Det er vist noget godt. Anna ${ }^{13}$ og Tilde og Frans ${ }^{14}$ er gået på lazarettet ${ }^{15}$ for at se til vore tappre [soldater]. Vi har endnu et par liggende her.

Lev vel, Eders moder.

Aabenraa, den 2. maj 1864.

Mine kjoere born.

Hvor vented vi længe efter Eders breve. Vi vidste 14 dage, før vi fik brevene, at I var ankommen til Schanghai. Der kom breve 
rundt $\mathrm{i}$ byen, men ingen til os. Dog endelig en aften kom postbudet med et brev. Fader og jeg var ene hjemme, og vi tændte lampen og satte os ind $i$ salen for at læse $i$ ro. Jeg havde næppe læst dit brev, lille Ingeborg, for der holdt en vogn for døren, og et ajeblik efter gâr doren op, og en østerigsk officer med tjener [træder ind]. Nu, vi pakkede brevene sammen, og jeg måtte straks til at lave aftensmad til ham og få sengen opredet $i$ salen, da han ikke vilde dele stue med den preussiske officer, som lå $\mathrm{i}$ standkvarter med tjener og 6 mand foruden. Hvad synes du? Ja, det er kuns lidt endda. Sommetider have vi haft 12 menige, 2 majorer, 2 stabsofficerer. Kan du tænke dig, hvordan de ligger? Det skal jeg fortælle dig. Der står 2 senge på kamret, som I havde, 2 servanter. Der ligger to officerer. På det øverste loft er senge opslået til en 12-14 mand. I salen ligger der også to på gulvet. Sidst lâ der en greve von Schwerin, en hauptmann. Han lå på gulvet, da sophaen ikke var lang nok til ham, så I kan tro, at vi er kjede af den tyske herlighed, og hvad det allerværste er. Pigen har været syg i længere tid. Netop den aften eders kjære breve kom, var hun falden tilbage og var meget dârlig. Nu er det en smule bedre med hende, og jeg håber med Guds hjælp, at hun snart må blive rask. Det er dobbelt galt, når pigen vandtes. Jeg måtte også ligge en tid, da jeg fik for meget de forste dage, Mathilde lå. Vi mâtte tage Anna Dahls i huset. som er endnu. sålænge til pigen rigtig kan gå lidt om igjen. Mutter Vanselov ${ }^{16}$ har vi også hver dag til hjælp. Du kan tænke, jeg har ikke engang kundet få tid til at læse Rasmus' brev og dit med, så fortumlet er jeg i mit hoved, og al den sorg og bekymring man har over vores stakkels land og vore tapre soldater, som lider så meget ondt. De have forladt Dybbol og måtte vige for overmagten, da vi må tænke på, de kun er mennesker, omendskjøndt de strider som lover. Sejren var tavs fra preussernes side, da de mistede mange tusinde mennesker, men vi mistede også mange, mange brave tappre. Vi regner vores tab til henved en 4000 mand fangne, sårede, døde. Kan man andet end være bedrøvet. Tyskerne have i det mindste 5000 fangne danske, som sidde i Spandau i Posen, og Gud ved hvor. Nu er preusserne igjen i færd med at gå op i Jylland. De stakkels jyder. De er allerede i Aarhus. Den 29. april er der gået en fransk og en dansk general ud til 
ostrigerne, som belejrer Friederitz og have bekjendtgjort von Gablenz, at fæstningen er rømmet, som alle de dansksindede blev glad ved, for sâ blev da ikke det dyrebare blod spildt. For fastningen skal de nok lade ligge, og sâ má de nok snart stikke af. Conferenzen har begyndt, og håber vi, at den gode Gud snart vil hjælpe de danske til sejer. Alle vi danske mennesker herhjem. me kan de ikke knuse modet pâ, om det have set nok så markt ud. Vi tror med fortrostning til Gud og er sikker på, han vil hjælpe. Vi ser kun sjeldent Skifter. Ludvig kommer. Han er nu bleven dansk. Han og Skifter enes nok ikke så godt. Ludvig fortæller, at det er ikke muligt at få nogen ting opgjort med ham ...

Nu har jeg skrevet sâ meget i dag, nu vil jeg onske, at du rigtig må være rask og munter, og du kjære Rasmus lev nu vel.

Jeres moder.

Aabenraa, den 6. august 1864 .

Kjare born.

Hvorledes har I det vel i Jeres hjem i skibet, nu da I har fået den velsignede lille dreng at pusle med? Han giver Jer vel alle nok at bestille, kan jeg tænke mig. Den ene er vel klogere på det end den anden af Eder. Tag ham kun godt $i$ agt, at I kan bringe ham rask hjem med Eder. Nu har vi allerede det ene år slidt, og når den gode Gud vil give os alle sundhed og helsen, så går det andet hen uden, vi ved om det at sige. Nu er drengen allerede 4 måneder gammel, og måske kender han allerede sin lille moder og fader. Jeg er så rolig for den lille unge, da jeg ved, at han har en moder, som vil passe ham tro og godt. Jeg vil dog hâbe kjære Ingeborg og Rasmus, at $I$ ere begge raske, og når I have sundheden, så er jeg overbevist om, at I er tilfreds og lykkelige med hinanden...

Nu lidt om krigen. Hovedkvarteret er for tiden i Aabenraa og har ligget her i 2 måneder, og Gud ved, hvornår det vil bort. Prins Carl bor hos Bruhns på mærkenet og har hele underste etage. Han holder tafel hver dag med hele stabet og musik hver aften pá torvet fra otte til ti. Vi have stadig en officer og en bursch og fire artillerister. For tiden ligger en baron von Fassen hos os, en meget net mand. Han rejser hjem til Berlin i disse dage igen. 
Desvarre ser det morkt ud for vort stakkels Danmark. For tiden er der en våbenhvile indgået på 12 uger, hvor Danmark har måttet afstå hertugdømmerne til Preussen. Hvis der ikke kommer et omsving i politikken, så er vi prisgivet til Preussen. Er det ikke noget af det værste, man kan tænke sig. Ingen vil hjælpe os, og selv kan vi ikke. Til den 19. september kan våbenstilstanden blive opkyndt, men så bliver der krig, og så går de over til Fyen, men nu mine kjæreste børn, når I modtager dette brev, så kan det måske se bedre ud for os, som nu. For vi danske have en stærk tro, omendskjønt vi ingenting have at støtte os til, så tror vi dog på en gud, som aldrig vil svigte os. Han hjælpe os $i$ denne trængselstid, at vi tror og har håb, som vi ikke kan tage af os selv, og når det ser allermorkest ud, så kommer Vorherre altid og hjælper dem, som tror på ham.

$\mathrm{Nu}$, mine kjære børn, lev nu vel og kys og hils Jeres lille dreng fra os alle. Hils Elberg og Paulsen.

Lev vel

Eders moder.

Aabenraa, den 8. august 1864 .

Min kjere Ingeborg.

Du vil vist nok se af mit brev fra den 6., at humøret har været dårligt, da jeg har skrevet så meget, som ikke skulde have stået, men da jeg nu en gang har skrevet det, må det hellere komme med, da jeg ved, du kjender din moders svagheder.

Fra Andreas ${ }^{17}$ har vi haft brev. Det var skrevet fra New York, hvorfra han er gået til Bahia som matros og får 14 specier om måneden. Det er med en dansk bark "Dora", flensborgerkaptajn Olsen. Andreas er munter og rask og har besøgt H. Hejdenheim, som bor i New York, og som har været så god imod ham. Hejdenheim skrev med samme post som Andreas til os. Han står sig godt derovre, og alle de danske søger ham, og han har hjulpet Andreas til (ulæseligt) og taget sig meget af ham. Man har venner, hvor man mindst tænker. Jeg skal fortælle dig, hvorledes det er gået med Andreas. Han deserterede fra hamburgeren $i$ New York, og der tog han hyre med en skonnert, som foer på kysten, som skulde gå til Baltimore, en engelskmand, hvor Hans Rødgaard og han var sammen. De havde det så godt om bord, 
som de kunde ønske, og derfor vilde de blive der, men så kommer der efterretninger, at rebellerne har taget Baltimore og brændt byen af, hvorfor skibet måtte lægge op, og folkene blev afmønstrede, og således gik det.

Jenny Fischer ${ }^{18}$ har haft bryllup i Assens for en 14 dage siden og sejler mellem Kjøbenhavn og Fyen. Ingen af forældrene var med, da de kunde vente angrebet på Fyen hver dag. Helene Dam ${ }^{19}$ giver bryllup på torsdag, kun meget lidt. Hun skal bo hos guldsmed Petersens. Tænk Jer blot, guldsmed Maller ${ }^{20}$ denne skinhellige djævel er så tysk. Ja, kære Rasmus, du skulde se et gran ind i vores lille by, da vilde du slå kors og tanke, at folk er bleven som glubende ulve, så slette. Ja, de er meget slettere, da de dog have forstand. De råber Hannemann efter dansksindede folk. Når vi ikke havde prinsen her, så skulde I se, hvorledes det skulde gå. Alle embedsmændene og præsterne i hele hertugdømmet er udjagede og har måttet døje så mange forhånelser for det, de er tro. De er bleven kastet $i$ hullet og $i$ forhør. Ja, det er ikke værd at tænke på, men pennen løber af sig selv. Frygt ikke for os. Vorherre skal nok bevare os, og nu Gud befalet.

Hils Jeres velsignede unge og kys ham og Jer selv fra os alle moder.

den 18. august 1864 .

Kjore Ingeburg.

I dag har vi stor stads i byen, da det er den østrigske kejsers fødselsdag. Kanonerne begyndte i morges kl. 5 og tappenstreg op gjennem alle gader. Hele byen er bekranset, og guirlander hænger tværs over gaden med navnet Franz Josef imellem. Fyrværkeri og fakkeltog $i$ aften og bal $i$ skoven og i byen med soldaterne, prinsen og hans officerer. I kan tro, vi er noget $i$ denne tid. Man kan nok mærke, det er noget stort at være tysk. Gid blot ikke, dette mátte vare for mange år. For det er meget tungt at vare $i$, men Vorherre give os vel mod til at holde ud. For vi håbe dog, at det bliver godt en gang igjen. Det er for resten et besynderligt spil, at de da alle er imod os, da de neutrale magter kan see vel den odelæggelse og slethed, som bliver udøvet imod os, uden i mindste måde at røre dem. Nej, vi står ene og forladt af den hele verden, men een er der, som kan hjælpe, og 
som vil, og det er Vorherre, men tiden or ikke kommen endnu, for efter storm kommer altid godtvejr, og sâ má vi tro, hvad vores lille Fanny siger og hjælpe os med det så lienge, til det bliver bedre. Det er da altid en trost. Du ved nok lille Ingeborg, at jeg altid har troet på hende for, men nu troer alle de danske på hende, for vi klamrer os til det mindste glimt for ikke at segne under byrden, for det må blive godt en gang, så sandt Vorherre lever.

J'g skal fortalle Eder lidt om Fanny, lige som jeg mâtte til Sophie. Hun skrev til Thilde om at fortalle lidt om Fanny, men hun kunde ikke. De to små piger skriver ofte til hverandre, så måtte jeg da til. Fra kaptajn Hansen og fra Fanny skal jeg hilse Jer så mangen gang. Han har været $i$ Hamburg og var hos os en halv times tid, da han blot holdt sig et par timer op her $i$ byen, men $i$ den anden tid sad han ved Fanny for at høre lidt om, hvorledes det skulde gå med de danske. Hun sagde ham så mange ting, som jo kunde fylde hele spalter, derfor vil jeg indskrænke mig til at fortælle Jer et lille uddrag deraf. Nu må I vide, at hun har sagt det længe for, det er kommen så vidt. For de danske skulde håbet reent være ude, og tyskerne skulde få landet og være så trygge derpå, som det aldrig skulde fra dem mere, men så vilde det også være forbi, og ingen vilde hjælpe, men alle vilde de have. Der vil komme franskmand og russere, inden krigen får ende, og der vil blive leveret et slag nord-vest for Aabenraa, og dermed skal krigen være endt. Da skal de danske sejre, og ingen kan nu fly. Vi skal komme til at høre kanonerne i byen, og der vil komme en stor forvirring i fjenden. Kjære Rasmus, når I dog kunde få nogen Berlingske Tidender derud, omendskjont de ikke bringer synderlig godt, så er det da altid en trost at have dem. De har været forbudt i længere tid, men nu er de kommen igjen. De underhandle i Wien nu. Preussen, Østrig og Danmark. Sidst dag læste jeg $i$ avisen et stykke ud af et fransk blad taget, hvor de havde haft flere debatter, Bismarck, den preussiske minister, som sagde til oberst Kaufmann, ${ }^{21}$ at de måtte vide, at de vare de besejrede. „Vel vide vi, at vi står lige over for en sejrherre, og at vi er de besejrede, men før begynde kampen påny, som gå ind på enhver fred. Nok ere vi de døende, men ikke døde. Kom så, vi er beredt, sæt kronen på værket, gå til Kø- 
benhavn. Der vi venter vores bødler med resignation. Give landsdelen bort, og sâ ville have penge oven i kjobet, nej, aldrig," svarede den danske gesandt. 'Tænk dig nu, hvor krænkende for sãdan en mand, som mener det arligt og redeligt med sit fædreland. Denne oberst Kaufmann er sådan en udmærket, dejlig mand. Han har ogsá været som parlamentær hos prinsen her $\mathbf{i}$ byen. Han måtte ligge over een nat, da prinsen ikke var hjemme. Han er nu en udmærket smuk mand og havde en ordonanlz med, som kunde måle sig med preusserne begge to. Herren og tjeneren. Vores officer kom hjem og fortalte, at de alle var blevet sâ indtaget af ham. Prinsen blev ganske forundret, da han modtog ham, sá modig og sả beleven en herre. Du kan tro, Lorenz var begejstret derover. Han sagde til mig. "Vi kan rigtignok være stolte af vores danske. Det kan nok være, at de kan mále dem med preusserne." Han var netop tilstede, da de kom. Vognen blev straks omringet af mennesker, som om det var udenlandske dyr. Ja, vi oplever meget. Gud ske lov, at I ikke er hjemme i denne tid. Gud give Eder sundhed og noget at fortjene, så holder I det nok ud så længe, det bliver godt igjenl. Nâr du nu skriver hjem, så adresser brevet til fader, da det sá nok skal komme tilstede. De åbner ikke brevene, og hils min broder så mange gange fra mig. Jeg er så glad ved, at han har Eder der at tale lidt med. Det lader ogsä til, at I have det muntert og selskabeligt, så går tiden godt mellem gode venner. Nu lev vel kjæreste born.

Eders hengivne moder.

Apenrade, den 20. oktober 1864.

Kjore born.

Tak for Jeres kjare breve, hroraf vi kunde se, at I rigtig have det godt, og at I leve imellem sá mange bekendte og venner. Familie og alle soger til Eders hjem $i$ "Johamne Marie". Vi glæder os rigtig derved. Snart kommer den ene med en hilsen, som har skreven hjem, om at have besogt Petersens, snart en anden. Det er jo altid sả gladeligt, og det kjare lille barn. Hvor det glader os at høre, at han kunde sidde $i$ sophaen og more sig, imedens du skrev, kjare Ingeborg. Han glæder Jer vist mangen gang, og han bliver jo altid morsommere og hver dag klogere. Gud give nu, at 
han mâtte fä sine tænder godt, til at han ikke skulde komme til at lide for meget. Du skrev, kjære Ingeborg, at han sadt i sin bare skjorte, men det kan da ikke vare ment. Han har da vel klæder ${ }^{22}$ på, den lille sjal. Om det er nok så varmt, să må hau dog holdes varm og isaer hans lille mave. Pas ham nu rigtig godt, og se selv også, at I kan beholde godt helsen og sundhed. Da vi fik Jeres brev, da lå jeg syg og havde ligget i en 3 ugers tid, og for jeg blev syg, havde Lorenz ligget ligeså længe. Da han blev syg, så syntes jeg, at jeg helst mátte passe ham, da doktoren sagde, at han skulde ligge ene, og der ingen måtle komme til ham, og Lorenz var endnu ikke rigtig kommet sig, førend jeg måtte lægge mig. Det var den gastriske feber, som rigtig er en slem sygdom, dà det varer så længe, inden man får kræfterne igjen. Men nu Gud ske tak, nu er det overståct, og nu ere vi raske igjen. Med Anna og lille Marie Callsen er det rigtig godt igjen. De er muntre. Callsen er afsat som brovant af vores tyske ovrighed. Han er rigtig ægte dansk. Ludvig Andersen er også dansksindet, men han. går så rolig og kommer ikke til nogen danske folk. Han er vist bange. Han bygger et skib som Eders og et stort 3 etagers hus med 3 altaner på og flag tage3 ved siden af Fischers, og der skal madam Andersen ${ }^{24}$ og Marie bo. Da Thilde giver bryllup i marz næste âr. To lejligheder kan fâs i samme hus til 100 daler hver, men sikken en lykke for Skifter. Nu kan han da gifte sig til sommeren. Det kan han alt takke Ludvig for. Vi var et pænt lille selskab. Callsens spiste til middag og lille Marie ${ }^{25}$. Anna talte ikke et ord til Serene ${ }^{26}$, og lille Marie sagde, „Tante Sikke (Serene) er tysk." Serene lo deraf. Ja, den Midde (Marie) er rigtig morsom. De havde en gammel hauptmann liggende så længe, og han holdt så meget af Midde og tjeneren med. Nâr vi nu spørger Midde om, hvad Quast sagde. Han hed nemlig Quast. Sâ siger hun, "Weg mit dir Hannemann", for Midde er dansk, og alle dem kalder de for Hannemann. Hauptmanden spurgte hende om (idet han pegede på hendes lille ende) "Was ist das, kleine Midde?" Så sagde hun, "mâsse". "Nein kleiner Popo", (svarede hauplmanden) "Nej, másse, onkel Hauptmand, " svarede hun. Hun kommer ganske ene gående om til os. Alle driller de hende. Du kan tro Callsen og Anna er glade ved hende. I dette øjeblik fik vi brev fra Andreas. Han har det rigtig godt, men var 
så bedrøvel, fordi han ikke havde fâet vore breve, som vi skrev til Bahia, og nu gik de til Rio, men måske han endnu kan fả dem. Nu skal de gâ til Lissabon for ordrer, og måske kan de komme her hjem efter. Han kan komme med Friedrich Callsen, som bygger en ny brig ved Jacobsen, ${ }^{27}$ for anden styrmand. Han vil gjerne have ham med. Han har bedt os om at skrive til ham derom. Det er en fætter til vores Callsen. Om politikken er der for tiden ikke meget at skrive. De venter freden hver dag, men den er ikke kommen endnu. Vi danske er ved godt háb og venter ganske rolig tiden af, og tyskerne de arbejder i deres borgerforening og gjør alting så galt, som de kan, men vi er nu vant dertil, og det anfægter os slet ikke mere. Sá kjære børn, lev nu vel og vær hilset af hele familien, men dog mest af Jeres

moder.

Aabenraa, den 2. 1. 1865.

Kjcere Ingeborg.

Jeg kan dog ikke andet, end jeg má skrive et par ord til Eder, omendskjønt hverken hovede eller pen dur noget, men jeg ved dog, at du vil blive glad ved det, hvorledes det så er. Forst ønsker jeg eder med samt det kjære lille barn et velsignet og godt nytár, og at vi snart måtte kunne se Eder raske og muntre. Nu flytter Ottzens bort, sâ har vi plads nok til Eder, nâr I engang kommer, måske til eftersommeren. Kan det ikke blive morsomt? Således taler vi med hinanden om Eder, og Cilie glæder sig dertil, at hun kan fâ den lille dreng at sysle med. Hils onkel Koch, ${ }^{28}$ når I taler med ham igen. Hvor det glæder mig, at din kjære Rasmus holder af ham, da det jo dog er en stor opmuntring for onkel, da han jo nu er en gammel mand og kan trange til folk, som mener det godt med ham. Jeg havde brev fra tante sidst. Hun var så glad ved, at Mathilde var kommen med sin fader. Vi skrev jo jævnligt til hinanden. Tante Elbergs ${ }^{29}$ de flytter nu til København til sommer. De har lejet udenfor Vesterport på en forste sal. Tante vilde nok have blevet, men onkel var kjed af det tyske væsen. Man kan ikke fortænke folk $\mathrm{i}$ det, nảr de kan rejse bort, at de gjor det. Vi har nu stadigt 3 mand indkvarteret. Det er kjedeligt, men vi skal jo holde ud, hảbende det engang bliver bedre. Vorherre give kun blot sundhed og lidt at fortjene, så 
bliver def nok godt igen. Vi har et godt hab, som aldrig svigter os. Fanny styrker os godt. Hun sagde sidst aften, da jeg var der, at de danske vilde snart komme herned igen. Ja, kjære Ingeborg og Rasmus, I skulde kun blot hore hende. Alt, som det er gået os, har hun sagt os det, fơr det kom sâ vidt for vores stakkels armé. Du kan tænke dig, da vore tropper endnu stod på Dannevirke, da var Richard Sørensen deroppe for at se, hvorledes det sa ud. Da han nu kom hjem, besogle han Fanny for at fortælle, hvor storartet det var befæstet. „Ja,“ salgde Fanny til ham, „det er slemt, at de har slæbt alt det skyts derop, da de dog ikke vil komme til at lasne et skud derfra". "Sá," sagde Richard og blev ganske forbloffet, „sá trækker de sig da tilbage til Dyppel, for den kan de da forsvare.“ „Nej,“ sagde hun. „Den skal tyskerne have og Als med. Vi skal miste alt for at fâ alt tilbage igen.." Jeg kunde fortalle dig meget om hende, men, nâr I, vil Gud, skal komme hjem, sá kan du fâ nok at hore. Anma besøger hende of te. Hun siger altid, at tiden løber sả hurtigt deromme. Thora kommer der. Fru Deichmann ${ }^{30}$ var hendes daglige gæst. Nu er Deichmanns flyttet til Faaborg og har kjøbt et bogtrykkeri og giver en avis ud, men han agter at komme tilbage igjen, nâr der kommer bedre tider. Nu nok om det. Nu kan jeg fortælle Jer, at vi have fáet Andreas hjem. Han er bleven høj og ser godt ud. Han gâr med en kaptajn Callsen for anden styrmand. Måske først i maj kan de komme bort. Det er rigtig, rigtig morsomt. Nu er Carl Fischer ${ }^{31}$ hjemme. Anton ${ }^{32}$ er også kommen i aften. Jeg sidder og skriver $i$ spisestuen. Stuen er fuld af unge herrer. Der er Jacob Michelsen, ${ }^{33}$ Anton Fischer, Carl Fischer, Theodor Sorensen, Johan, Andreas, Lorenz og Cilie spiller, og de synger alle sâ yndigt. Dén yndige sang, "pá forposl". Du kan tro, vi har fäel dejlige nye krigssange, som vores ungdom synger med begejstring. I dette njeblik synger de "Stolt med oprejst pande". Jeg er ganske henrykt, og dog foler jeg det klinger nogel vemodigl, som uvilkårligt rorer sig i hjertet, som man ikke kan lilbagetrænge. Du kan tro, Andreas har fået sig omseet. Han rejste fra Triest over land hjem. Han kan ikke nok fortælle, hvor dejligt det var igjennem det sachsiske Schweitz. Jernbanen gar igjennem de højeste klipper og over broer, hvor dalen med små landsbyer ligger mange tusind fod nedenfor. 
Kjare søster og suoger.

I lang tid har vi nu ikke hørt fra hinanden, undtagen hvad fader kunde skrive til os, hvor vi befandt os, såvel den ene som den anden, men nu da jeg er herhjemme, og der just skal skrives til Eder, så vilde jeg da også sende Eder et par ord, for at I kan se, jeg endnu er levendes. Jeg kom her til byen sidste mandag over land fra Triest, så jeg var midt inde at se det store tyske fædreneland. Det var for resten en interessant rejse at gjøre, men den kostede også interessante penge, men det må nu hjælpe sig. Jeg er jo nu som sagt herhjemme, og fader ville jo gerne have mig med en brig, som bliver bygget her til Frederik Callsen, og jeg har jo også nok lyst dertil, men den går jo ikke før $\mathbf{i}$ april måned, og det er jo længe nok at ligge herhjemme og vente. I kan tro, der er sket forandring herhjemme, siden vi gik herfra. Denne tid vajede dannebrogen over vor lille by, men nu, hvor man vender sig hen, ser man ikke andet end den trestribede jammerpjalt svæve fra husene. Det skar i mig de første gange, da jeg så dem, og ærgrede mig, men nu vænner man sig dertil og håber på bedre tider, og efter min mening vil de ikke længe udeblive, og når først timen slår, da ve disse elendige, som først lod den forhadte fane svæve. Jeg ville ønske, at krigen ville bryde løs, førend at jeg drog bort herfra, for at jeg kunde tage deel deri, men det bliver der jo sagtens ikke noget af. Ja, kjære, jeg håber, at inden I kommer her tilbage til byen, vil vi have dannebrogen over vor by igjen.

I hilses fra Jacob, som just står ved siden og holder mig op med snak, og fra alle, som ellers I kjender, men mest fra Eders broder og svoger.

\section{Andreas}

Lev vel og skriv mig til igen.

Apenrade, den 21. marts 1865.

Min kjoere Ingeborg.

Du kan tro, der blev glæde, da vi fik Eders kjære breve og så, at I var sunde og godt tilfreds allesammen. Gud ske tak, at I har det kjære lille barn at glæde Jer ved, og vi håber nok, at det ikke må vare så længe, inden vi må ses og samles alle fornøjet og glade igen i vort lille Aabenraa, som jo rigtignok for tiden er tysk, men 
måske til den tid kan blive dansk. Så vilde vi være dobbelt glade. Der tales for øjeblikket om en afståelse af det nordlige Slesvig, og at de underhandle derom er ganske vist. På den anden side af Flensburg ved Slilinien, så kunde vi være godt tilfreds, men Fanny siger, at dansken skal have det hele igen, og at preusserne skal udslåes, og hun håber ikke, at det vil vare ret længe, inden de vil begynde igen. Jeg var forleden dag henne hos Fanny for at se, hvorledes hun havde det, da hun er meget syg i denne tid. Da fortalte hun mig, at alle troede, at hun ikke levede, men hun døde ikke i Persillegaden. Hun skal leve krigen over og være rask, når de danske kommer igen. For de skal sejre. Hvad siger I dertil? Det er da altid en trøst for stakkels danske folk. I morgen er det vores konges fødselsdag. Dog det vil da sige vor preusser konges. For vi have for tiden 3 herskere, som vi jo alle gør stads af. I sommer var det vores Kaisers geburtstag. Da blev der kanoner kørt op på broen, og så saluterede de, så Callsens måtte tage alle deres vinduer op for ikke at få dem sprængt, og adskillige ruder sprang på sejlmageriet. Hele byen var bekranset og så mange kulørte faner, ja det var storartet, og på vores Herzogs indtog. Den dags dato blev om aftningen på Kolstrupbakke og 4 steder mere brændt tjæretønder af, så I kan jo nok tænke Jer, at vi er bleven til noget. Det er sandt, du kan tro, at Serene er i vælten. Hun får det ene stykke tøj efter det andet. Hun har så mange kjoler og madammen også. Hun er så vigtig. Alle officerer kommer til dem. Kommandanten og den provisoriske borgmester. De spiser „Frühstück“ hos fru Tyroll ${ }^{35}$ og sidder mest hele dagen. Forresten fortjener hun mange penge, som man godt kan unde hende, da hun er en gammel kone. Hellere hos Tyrolls, som på Stadt Hamborg, for det er rigtig nogen banditter. Når Serene nu ingen kjæreste kan få, så ved jeg ikke, hvad jeg skal sige. Anna og Serene står meget spændt. De taler aldrig sammen. Jeg skal hilse Jer så meget fra Cille. På Eders lille Fritzes fødselsdag, den 17. kan I tro, hun fejrede. Hun var ikke i skole, og så bad hun Lise Sødergreen til chokolade med flødeskum, og hun længes efter, at I da snart skal komme hjem. Så lev vel kjære børn og hils og kys Jeres lille dreng og Jer selv fra Eders hengivene

moder.

Lev vel og kom snart hjem. 


\section{NOTER}

1. Gasværket oprettedes i dette år.

2. Kaptajn Rasmus Petersen. Svigersønnen.

3. En hushjælp.

4. Præstedatter fra Ảbenrå, senere gift med J. P. Junggreen i hans andet agteskab.

5. M. C.'s døtre og søn.

6. Richard Sørensen, søn af redaktør Nicolaj Sørensen.

7. Billedskærer af gallionsfigurerne til sejlskibene.

8. Skibsbyggeri.

9. Kaptajn Ludvig Andersen, søn af skibsbygger Thorkild Andersen.

10. Skibsbygmester Skifter Andersen, senere direktor for skibsværft i Kobenhavn.

11. En ganske uretfærdig beskyldning fremkaldt af deres mere objektive bedømmelse af krigssituationen.

12. M. C.'s barnebarn, søn af Ingeborg og Rasmus Petersen.

13. M. C.'s datter, gift med kaptajn Frederik Callsen, senere med J. P. Junggreen i hans fjerde ægteskab.

14. Søn af Anna Callsen, opkaldt efter Jomfru Fanny (Franciska).

15. Indrettet på rådhuset og på skolen ved Skolevej.

16. Kendt strygerske.

17. M. C.'s ældste søn.

18. Søster til kaptajn C. C. Fischer, Abenrå.

19. Datter af konsul Dam, Ảbenrå.

20. C. Moller, født den 15. 2. 1815, tilflyttet fra Fåborg.

21. Oberst Kauffmann ved 2. brigade.

22. Bleer.

23. Ejendommen Skibbroen 10.

24. Enke efter skibsbygger Thorkild Andersen.

25. M. C.'s barnebarn, datter af Anna Callsen.

26. Datter af smedemester $P$. Tyroll og hustru Wolbestine, fodt i Tønning, gift i 1868 med toldassistent Max Böthefür fra Glückstadt.

27. Skibsbygmester Niels Jacobsen, Åbenrå.

28. M. C.'s broder.

29. Kaptajn og skibsreder N. L. Elberg.

30. Krigsassessor Deichmann var skolebestyrer ved højere dansk drengeskole i Ảbenrå fra 1858-64.

31. Kaptajn C. C. Fischer, Ảbenrå.

32. Bror til C. C. Fischer.

33. Løjtnant og gårdejer Jacob Michelsen, Kolstrup.

34. Søn af redaktør Nicolaj Sørensen, Ảbenrå.

35. Wolbestine Tyroll, enke efter smedemester Peter Tyroll, Ảbenrå. 